\title{
ANALISIS INTENSITAS DAN COVERAGE PROSES SHOT PEENING TERHADAP TEGANGAN SISA DAN KEKERASAN PADUAN AL 7075 T7351
}

\author{
Agus Fikri' ${ }^{1}$, Rifky ${ }^{1}$, Mohammad Yusuf Djeli ${ }^{1}$ \\ Program Studi Teknik Mesin \\ Fakultas Teknik, \\ Universitas Muhammadiyah Prof.DR.HAMKA, Jakarta \\ agus_fikri@uhamka.ac.id,rifky@uhamka.ac.id, moh_yusufd@uhamka.ac.id
}

\begin{abstract}
Abstrak
Shot peening merupakan metode pengerjaan dingin dengan menumbukkan permukaan logam menggunakan partikel-partikel bulat yang berukuran kecil dan berkecepatan tinggi. Dengan proses shot peening dapat dikurangi inisiasi dan propagasi retak yang menyebabkan terjadinya kegagalan terhadap logam. Tujuan penelitian ini adalah untuk mengetahui pengaruh intensitas dan coverage shot peening terhadap tegangan sisa dan kekerasan pada permukaan Al 7075 T7351. Penelitian dilaksanakan dengan menembakkan permukaan logam dengan intensitas 0,0062 A dan 0,0091 A, serta coverage masing-masing 100\% dan 200\%, kemudian dilakukan pengujian kekerasan permukaan dan tegangan sisa. Hasil penelitian menunjukkan bahwa shot peening menyebabkan terjadinya perubahan tegangan sisa, yaitu 92,5021 MPa pada keadaan tanpa shot peening menjadi-111,8726 sampai -170,5675 MPa setelah dilakukan dishot peening. Selain itu kekerasan pada permukaan meningkat antara 23,4\% sampai dengan 44,7\%. Meningkatnya kekerasan menunjukkan bahwa terjadi pengerjaan dingin yang besar pada permukaan logam. Pengaruh pelapisan (coverage) 200\% ternyata meningkatkan besarnya tegangan sisa dan kekerasan permukaan walaupun belum melampaui intensitas yang lebih besar.
\end{abstract}

Kata kunci : shot peening, intensitas, coverage, kekerasan permukaan, tegangan sisa

\begin{abstract}
Shot peening is a cold working method by striking metal surfaces using small, high-speed and round particles. Shot peening can reduce the initiation and propagation of cracks that cause metal failure. The purpose of this analysis is to determine the effect of shot peening intensity and coverage on residual stress and hardness on the surface of Al 7075 T7351. The research was carried out by firing metal surfaces with intensities of $0.0062 \mathrm{~A}$ and $0.0091 \mathrm{~A}$, and coverage of $100 \%$ and $200 \%$, respectively, then testing surface hardness and residual stress. The results showed that shot peening caused a residual stress change, which was $92.5021 \mathrm{MPa}$ in the state without shot peening to -111.8726 to $-170.5675 \mathrm{MPa}$ after it was shot peening. In addition, surface hardness increased from $23.4 \%$ to $44.7 \%$. Increased hardness indicates that there is large cold working on the metal surface. The effect of $200 \%$ coverage apparently increases the amount of residual stress and surface hardness even though it has not exceeded the greater intensity.
\end{abstract}

Keywords: shot peening, intensity, coverage, surface hardness, residual stress

\section{PENDAHULUAN}

Proses kegagalan atau kerusakan yang terjadi pada bagian tertentu dari struktur dimulai dengan munculnya awal retak (inisiasi), bagian ini biasanya sulit sekali dideteksi karena dipengaruhi oleh berbagai hal, diantaranya adalah karakteristik material, dan perlakuan yang mengenainya baik secara mekanis maupun kimiawi pada bagian permukaan material sehingga muncul awal retak. Kemudian setelah masa inisiasi selesai dilanjutkan dengan penjalaran retak (propagasi) yang juga dapat berlangsung secara lambat ataupun cepat tergantung dari karakteristik material dan tegangan yang telah ada dalam bagian yang sedang mengalami proses menuju kegagalan tersebut. Tegangan yang telah ada pada saat proses inisiasi dan propagasi tersebut disebut sebagai tegangan sisa (residual stress) yang sifatnya dapat merusak, karena mempengaruhi awal retak dan penjalaran retak.

Tegangan sisa itu sendiri dapat dibagi menjadi tegangan sisa tarik (tensile residual stress) dan tegangan sisa tekan (compressive residual stress) yang sifatnya saling bertolak belakang. 
Tegangan sisa tarik sifatnya merusak, karena mempercepat timbulnya awal retak dan penjalaran retak, tegangan sisa jenis ini dapat timbul karena perlakuan mekanis dan perlakuan panas yang dialami material. Sedangkan tegangan sisa tekan sifatnya menghambat kerusakan, karena memperlambat timbulnya awal retak dan penjalaran retak, tegangan sisa ini dapat timbul karena adanya perlakuan mekanis khusus yang diterima permukaan material.

Metode yang dapat dipergunakan untuk memunculkan tegangan sisa tekan pada permukaan material adalah perlakuan permukaan shot peening. Dengan shot peening dapat menghambat kegagalan akibat fatique dan korosi retak tegang (stress corrosion cracking) (Okido., et al., 2002). Perlakuan permukaan ini dilakukan dengan cara menembakkan permukaan suatu komponen atau struktur dengan partikel-partikel bulat yang berukuran kecil berkecepatan tinggi dan biasanya partikel-partikel tersebut terbuat dari besi tuang, baja tuang, serbuk glass, dan keramik. Proses penembakan oleh partikel-partikel kecil tersebut dilakukan dengan intensitas dan cakupan daerah (coverage) tertentu.

Dengan dilakukannya proses shot peening akan terjadi perubahan sifat pada permukaan material, seperti yang telah diuraikan diatas, yaitu munculnya tegangan sisa tekan, disertai dengan perubahan kekerasan pada permukaan material, yang besar masing-masingnya tergantung pada material yang digunakan, intensitas dan coverage dari proses shot peening yang dilakukan.

Proses shot peening banyak diaplikasikan untuk logam ferrous terutama baja, serta logam non ferrous. Untuk logam non ferrous material yang sering menggunakan aplikasi tersebut adalah aluminium karena dalam penggunaannya perlu dilakukan perlakuan panas (heat treatment) yang menyebabkan permukaannya menjadi lebih keras sehingga mudah terjadi inisiasi retak.

Material aluminium yang diberi perlakuan shot peening pada permukaannya dalam penelitian ini adalah paduan Al 7075 T7351, yang dalam aplikasinya digunakan secara luas pada aircraft structural partsdan aplikasi struktural tegangan tinggi lainnya dimana kekuatan dan ketahanan korosi yang tinggi sangat dibutuhkan.

\section{RUMUSAN MASALAH}

Berdasarkan uraian pada latar belakang diatas, maka diperlukan pendalaman tentang jenis tegangan sisa yang dihasilkan pada permukaan paduan Al 7075 T7351 setelah dikenai proses shot peening, serta seberapa besar pengaruh shot peening terhadap tegangan sisa dan kekerasan yang dihasilkan

\section{TUJUAN PENELITIAN}

1. Mengetahui pengaruh intensitas proses shot peening terhadap tegangan sisa (residual stress) dan kekerasan pada permukaan paduan Al $7075 \mathrm{~T} 7351$.

2. Mengetahui pengaruh pelapisan permukaan (coverage) $200 \%$ terhadap tegangan sisa dan kekerasan pada permukaan paduan Al 7075 T7351. 


\section{TINJAUAN PUSTAKA}

\subsection{Shot Peening}

Shot peening adalah salah satu metode perlakuan permukaan secara mekanis yang paling efektif, umumnya diaplikasikan untuk meningkatkan ketahanan terhadap fatik (fatigue) (Mahmoudi., et al., 2016), dan korosi retak tegang (stress corrosion cracking) (Okido., et al., 2002). Permukaan logam ditembaki dengan menggunakan partikel-partikel bulat yang berukuran kecil berkecepatan tinggi, partikel-partikel tersebut biasanya terbuat dari baja tuang, besi tuang, serbuk glass, atau keramik. Setelah dilakukan proses shot peening diharapkan muncul tegangan sisa tekan (compressive residual stress) pada permukaan material. Perlakuan permukaan ini digunakan secara luas pada automobile, power generation, dan aerospace industries (Torres \& Voorwald, 2002).

Peningkatan ketahanan terhadap fatik dengan menggunakan shot peening adalah dengan munculnya tegangan sisa tekan pada lapisan permukaan (surface layer), yang membuat nucleation atau inisiasi (initiation) dan propagasi (propagation) fatigue cracks lebih sulit terjadi (Torres \& Voowald, 2002), demikian pula mekanismenya terjadi pula pada kegagalan akibat korosi retak tegang, dengan adanya tegangan sisa tekan setelah dilakukan proses shot peening akan mencegah rusaknya oxide film pada permukaan (Okido., et al., 2002).

Pada banyak material timbulnya tegangan sisa tekan pada permukaan material juga disertai dengan peningkatan kekerasan pada permukaan yang ditimbulkan oleh pengerjaan dingin (cold work) yang dialami akibat proses shot peening (Klotz., et al., 2018).

\subsection{Coverage dan Intensitas Peening}

Coverage dan intensitas yang dihasilkan oleh proses shot peening sangat mempengaruhi besarnya tegangan sisa tekan yang dihasilkan (Klotz, Delbergue, Bocher, Levesque, \& Brochu, 2018), sehingga pada akhirnya berpengaruh terhadap ketahanan suatu komponen terhadap fatik dan korosi retak tegang.

Coverage menunjukkan seberapa besar luas permukaan benda kerja yang tertembak oleh partikel-partikel shot. Coverage $100 \%$ artinya seluruh permukaan telah tertembak dengan sempurna, tetapi dalam kenyataannya hal tersebut sulit untuk dapat diwujudkan, karenanya nilai coverage telah dianggap sempurna jika telah mencapai $98 \%$ dari total area yang ditembak oleh partikel shot. Untuk mendapatkan coverage lebih besar dari 100\%, penembakan dilakukan dengan waktu tembak selama waktu saturasi dikalikan dengan persen coverage yang diinginkan, misalnya untuk mendapatkan coverage $200 \%$, waktu tembaknya yaitu 2 kali waktu saturasi coverage $100 \%$.

Intensitas peening tergantung pada kecepatan, kekerasan, ukuran, besar partikel shot dan sudut tembak antara partikel shot dengan permukaan benda kerja. Semakin besar intensitas yang diberikan maka kedalaman lapisan tegangan sisa tekan akan semakin besar. Untuk menentukan besarnya intensitas, digunakan specimen standar yang disebut almen strip. Almen strip yang belum ditembak diletakkan pada specimen holder, kemudian permukaannya ditembak dengan partikel shot dengan waktu tertentu hingga terjadi defleksi. Besarnya defleksi ini menyatakan besarnya intensitas yang terjadi. 


\subsection{Paduan Al-Zn-Mg}

Paduan Al-Zn-Mg merupakan bagian penting di dalam kelompok paduan aluminium yang dapat dilaku panaskan, yang mana paduan ini termasuk dalam seri 7XXX. Kelebihan paduan ini mempunyai kekuatan tertinggi dibandingkan paduan aluminium lainnya, selain itu paduan ini mempunyai respon terhadap perlakuan panas (pengerasan presipitasi) yang paling besar. Kerentanan paduan ini terhadap korosi retak tegang telah diminimalkan dengan penambahan kromium dan dengan proses perlakuan panas yang tepat.

$\mathrm{Zn}$ dan $\mathrm{Mg}$ merupakan elemen paduan utama didalam paduan $\mathrm{Al}-\mathrm{Zn}-\mathrm{Mg}$, rasio $\mathrm{Zn}$ dan $\mathrm{Mg}$ yang tinggi menghasilkan kekuatan terbaik dan memberikan respon yang terbesar terhadap perlakuan panas, tetapi mempunyai kelemahan terhadap korosi retak tegang. Rasio Zn dan $\mathrm{Mg}$ yang rendah menghasilkan sifat mampu las dan stabilitas dimensi yang baik. Rasio $\mathrm{Zn}$ dan $\mathrm{Mg}$ juga menentukan pembentukan senyawa-senyawa seng. Jika rasionya lebih besar dari 2 maka akan terbentuk endapan (presipitat) $\mathrm{MgZn}_{2}$, jika rasionya lebih kecil dari 2 maka akan terbentuk endapan $\mathrm{Mg}_{3} \mathrm{Zn}_{3} \mathrm{Al}_{2}$ (Campbell, 2008).

\section{METODOLOGI PENELITIAN}

Penelitian ini dilakukan melalui beberapa tahapan yaitu pra penelitian yaitu persiapan sampel, pelaksanaan penelitian dengan menembakkan permukaan dengan proses shot peening, pelaksaan pengujian, dan analisis.

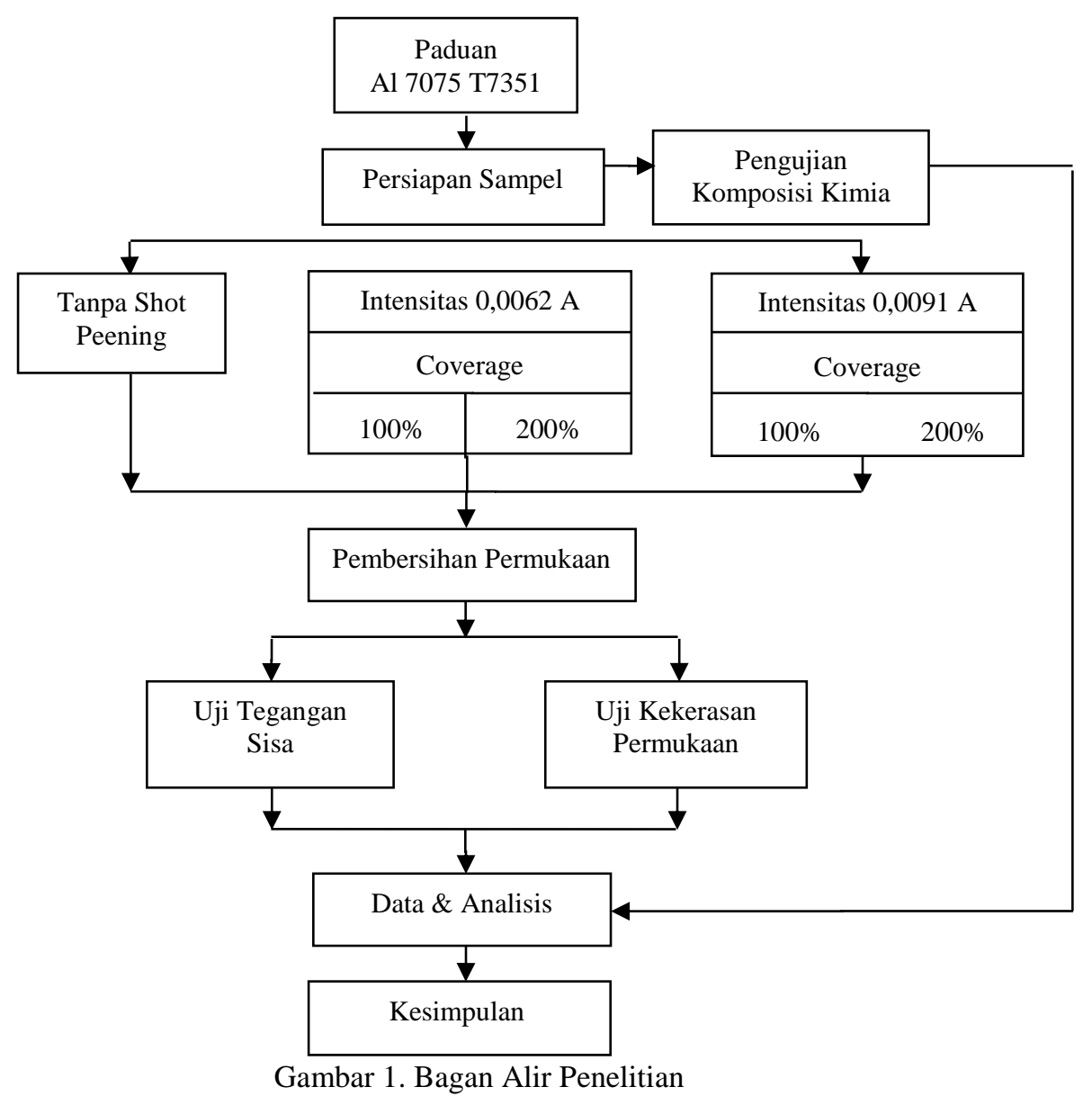




\section{HASIL DAN PEMBAHASAN}

\subsection{Komposisi Kimia dan Kekerasan}

Setelah dilakukan pengujian komposisi kimia dan kekerasan baik pada permukaan maupun sampai kedalaman $1450 \mu \mathrm{m}$, didapat hasil seperti ditunjukkan pada tabel 1 dan tabel 2 dibawah.

Tabel 1. Hasil pengujian komposisi kimia Al 7075 T7351

\begin{tabular}{cccc}
\hline Unsur & Kadar $(\%)$ & Unsur & Kadar $(\%)$ \\
\hline Aluminium $(\mathrm{Al})$ & 89,43 & Silikon $(\mathrm{Si})$ & 0,08 \\
Seng $(\mathrm{Zn})$ & 5,75 & Mangan $(\mathrm{Mn})$ & 0,04 \\
Magnesium $(\mathrm{Mg})$ & 2,58 & Krom $(\mathrm{Cr})$ & 0,21 \\
Tembaga $(\mathrm{Cu})$ & 1,77 & Titanium $(\mathrm{Ti})$ & 0,02 \\
Besi $(\mathrm{Fe})$ & 0,12 & & \\
\hline
\end{tabular}

Tabel 2. Hasil pengujian kekerasan

\begin{tabular}{|c|c|c|c|c|}
\hline \multirow{2}{*}{ Kondisi } & \multirow{2}{*}{$\begin{array}{c}\text { Jarak Dari } \\
\text { Permukaan }(\mu \mathrm{m})\end{array}$} & \multirow{2}{*}{$\begin{array}{c}\text { Kekerasan Tanpa } \\
\text { Shot Peening (VHN) }\end{array}$} & \multicolumn{2}{|c|}{ Kekerasan (VHN) } \\
\hline & & & Coverage $100 \%$ & Coverage $200 \%$ \\
\hline \multirow{6}{*}{$\begin{array}{l}\text { Tanpa Shot } \\
\text { Peening }\end{array}$} & 0 & 125 & & \\
\hline & 50 & & 155 & 158 \\
\hline & 150 & & 142 & 144 \\
\hline & 250 & & 125 & 130 \\
\hline & 350 & & 126 & 124 \\
\hline & 450 & & 126 & 126 \\
\hline Shot Peening & 550 & & 125 & 124 \\
\hline Intensitas & 650 & & 124 & 123 \\
\hline \multirow[t]{13}{*}{$0,0062 \mathrm{~A}$} & 750 & & 125 & 124 \\
\hline & 850 & & 122 & 125 \\
\hline & 950 & & 124 & 126 \\
\hline & 1050 & & 123 & 126 \\
\hline & 1150 & & 127 & 124 \\
\hline & 1250 & & 122 & 123 \\
\hline & 1350 & & 122 & 123 \\
\hline & 1450 & & 123 & 121 \\
\hline & 50 & & 175 & 182 \\
\hline & 150 & & 160 & 173 \\
\hline & 250 & & 136 & 150 \\
\hline & 350 & & 127 & 138 \\
\hline & 450 & & 127 & 124 \\
\hline Shot Peening & 550 & & 125 & 127 \\
\hline Intensitas & 650 & & 126 & 125 \\
\hline \multirow[t]{8}{*}{$0,0091 \mathrm{~A}$} & 750 & & 123 & 127 \\
\hline & 850 & & 125 & 126 \\
\hline & 950 & & 122 & 126 \\
\hline & 1050 & & 125 & 122 \\
\hline & 1150 & & 120 & 125 \\
\hline & 1250 & & 124 & 124 \\
\hline & 1350 & & 123 & 124 \\
\hline & 1450 & & 122 & 125 \\
\hline
\end{tabular}

Berdasarkan hasil pengujian komposisi kimia yang dilakukan pada material, dapat diketahui bahwa $\mathrm{Zn}$ dan $\mathrm{Mg}$ merupakan paduan utama. Adanya $\mathrm{Zn}$ akan meningkatkan kekerasan dan respon terhadap perlakuan panas, tetapi menurunkan ketahanan terhadap korosi retak tegang (stress corrosion cracking, SCC), oleh karena itu diperlukan keberadaan unsur lain dalam 
jumlah kecil yang dapat meningkaatkan ketahanan terhadap SCC, yaitu $\mathrm{Cr}$, yang besarnya menurut tabel 1 adalah $0,21 \%$.

Rasio $\mathrm{Zn}$ dan $\mathrm{Mg}$ berdasarkan tabel 1. adalah lebih besar dari 2, maka dapat ditentukan bahwa senyawa yang terbentuk pada matriks aluminium adalah fasa $\mathrm{MgZn}_{2}$, senyawa inilah yang menyebabkan terjadinya penguatan pada paduan $\mathrm{Al} 7075 \mathrm{~T} 7351$. Fasa $\mathrm{MgZn}_{2}$ tersebut dapat dilihat pada gambar 2 dibawah, yaitu struktur mikro Al 7075 T7351, dimana fasa tersebut tersebar diseluruh bagian, baik pada batas butir maupun didalam butir.

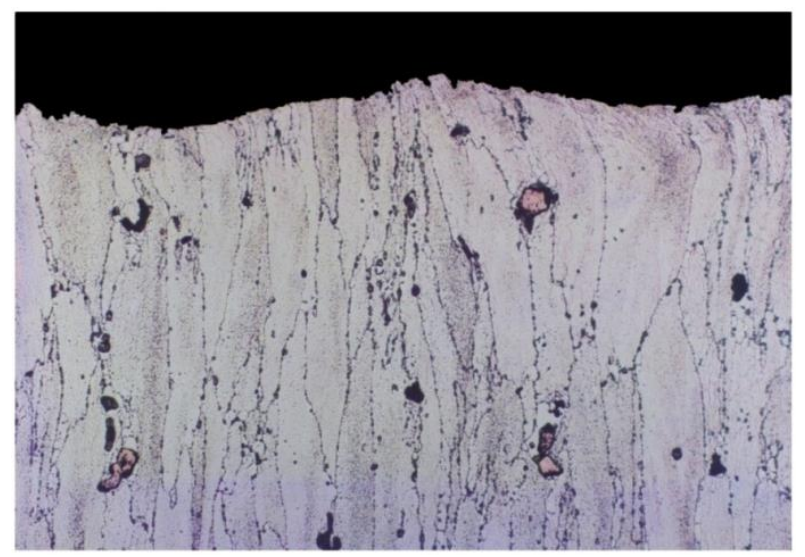

Gambar 2. Struktur mikro Al 7075 T7351 setelah dilakukan shot peening

Selain unsur paduan diatas $(\mathrm{Zn}, \mathrm{Mg}$ dan $\mathrm{Cr})$ perlu diperhatikan keberadaan tembaga $(\mathrm{Cu})$ yang dari hasil pengujian komposisi kimia adalah sebesar 1,77\%. Dimana keberadaan $\mathrm{Cu}$ tersebut akan meningkatkan kekuatan paduan. Dalam hubungannya dengan ketahanan terhadap korosi, $\mathrm{Cu}$ akan menyebabkan penurunan terhadap korosi umum, tetapi akan meningkatkan ketahanan terhadap korosi SCC.

\subsection{Kekerasan Hasil Shot Peening 0,0062 A}

Seperti yang dinyatakan dalam tabel 2 diatas, kekerasan material yang tidak dilakukan proses shot peening adalah $125 \mathrm{VHN}$. Setelah di shot peening dengan intensitas 0,0062 A, maka kekerasan pada bagian permukaan $(50 \mu \mathrm{m}$ dari permukaan) meningkat menjadi 155 dan 158 VHN, pada coverage $100 \%$ dan $200 \%$. Peningkatan nilai kekerasan tersebut setelah di shot peening menandakan bahwa permukaan material mengalami pengerjaaan dingin (cold working) akibat tumbukan dari partikel shot.

Meningkatnya kekerasan pada permukaan material hasil shot peening tersebut dapat dijelaskan dengan mekanisme pengerasan regang (strain hardening), dengan adanya tumbukan partikel shot pada permukaan material, maka akan terjadi deformasi yang menyebabkan peningkatan jumlah dislokasi, sehingga interaksi antar dislokasi akan meningkat dan membentuk penghalang terhadap pergerakan dislokasi lainnya, akibatnya diperlukan energi yang lebih besar bila dilakukan deformasi lebih lanjut. Sehingga ketahanan terhadap deformasi meningkat yang ditunjukkan dengan peningkatan kekerasan.

Kekerasan material yang dishot peening baik dengan coverage 100\% maupun 200\% berangsur-angsur turun sejalan semakin jauh dari permukaan, seperti dapat dilihat pada gambar 3 dibawah. 


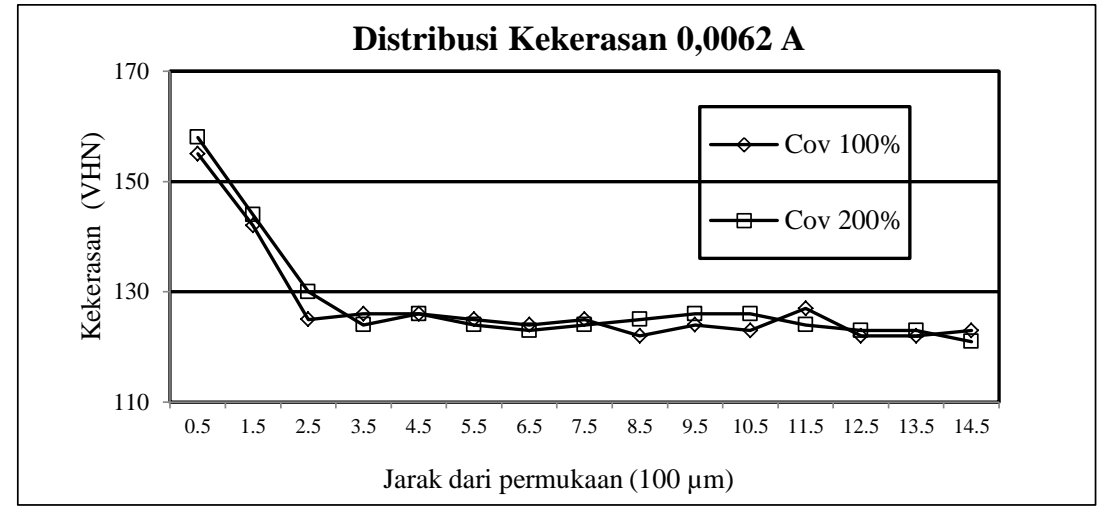

Gambar 3. Distribusi kekerasan setelah di shot peening $0.0062 \mathrm{~A}$

Distribusi kekerasan hasil shot peening dengan intensitas 0,0062 A dimulai dari permukaan dengan kekerasan tertinggi kemudian turun secara drastis hingga didapatkan kekerasan dengan harga yang dapat dikatakan tidak berubah lagi yaitu sekitar 121 sampai $130 \mathrm{VHN}$. Kedalaman pengaruh proses shot peening pada intensitas 0,0062 A dengan coverage 100\% dan $200 \%$ adalah antara $150-250 \mu \mathrm{m}$.

\subsection{Kekerasan Hasil Shot Peening 0,0091 A}

Sejalan dengan meningkatnya intensitas shot peening maka kekerasan pada bagian permukaan akan meningkat pula. Kekerasan material pada bagian permukaan $(50 \mu \mathrm{m}$ dari permukaan) dengan penggunaan intensitas sebesar 0,0091 A adalah $175 \mathrm{VHN}$ pada coverage $100 \%$ dan 182 VHN pada coverage $200 \%$.

Kekerasan yang terbentuk dengan peningkatan coverage dari $100 \%$ menjadi $200 \%$ pada intensitas yang sama, yaitu 0,0062 A dan 0,0091 A ternyata tidak menyebabkan peningkatan kekerasan yang besar dibandingkan pada peningkatan intensitas.

Seperti pada penggunaan intensitas 0,0062 A, kekerasan material akan semakin turun secara drastis sejalan dengan makin jauhnya jarak penjejakan dari permukaan material, seperti dapat dilihat pada gambar 4 dibawah.

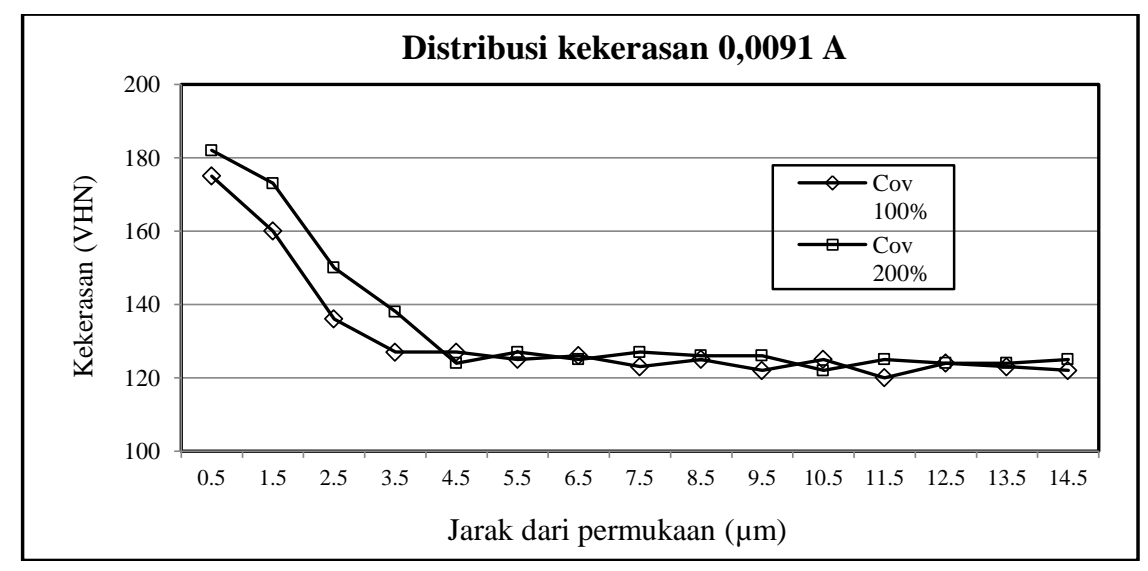

Gambar 4. Distribusi kekerasan setelah di shot peening 0,0091 A 
Kedalaman pengaruh penembakan dengan intensitas 0,0091 A baik pada coverage 100\% maupun $200 \%$ meningkat dibandingkan penggunaan intensitas 0,0062 A, yaitu sekitar 250 $\mu \mathrm{m}$ pada coverage $100 \%$ dan $350 \mu \mathrm{m}$ pada penggunaan coverage $200 \%$ berdasarkan hasil pengujian distribusi kekerasan diatas.

Kekerasan yang dicapai pada intensitas 0,0091 A lebih besar dibandingkan dengan intensitas 0,0062 A, hal ini dapat terjadi karena dengan intensitas tumbukan yang semakin besar, maka deformasi yang terjadi pada permukaan material akan semakin besar, sehingga terjadinya penghalangan pergerakan dislokasi menjadi semakin besar, sehingga kekerasan meningkat.

Akibat proses shot peening akan terbentuk lekukan-lekukan kecil, seperti dapat dilihat pada gambar 2 diatas, yang apabila secara satuan akan membahayakan, karena pada daerah tersebut akan terjadi sumber kegagalan terhadap komponen karena adanya konsentrasi tegangan pada lekukan tersebut. Tetapi karena lekukan-lekukan yang terjadi adalah dalam jumlah yang besar maka pada permukaan akan terjadi distribusi tegangan pada setiap lekukan, disamping itu tegangan yang ditimbulkan oleh proses shot peening adalah tegangan sisa tekan (compresive residual stress) yang akan menghambat awal terjadinya kegagalan pada pada suatu komponen.

\subsection{Tegangan Sisa}

Hasil pengujian tegangan sisa (residual stress) dapat dilihat pada tabel 3 dibawah, pengujian dilakukan dengan menggunakan X-Ray Difraction.

Tabel 3. Hasil Pengujian Tegangan Sisa

\begin{tabular}{ccc}
\hline No & Kondisi & Tegangan Sisa $(\sigma, \mathrm{MPa})$ \\
\hline 1 & Tanpa Shot Peening & 92,5021 \\
2 & Shot Peening 0,0062 A, 100\% & $-111,8726$ \\
3 & Shot Peening 0,0062 A, 200\% & $-113,1122$ \\
4 & Shot Peening 0,0091 A, 100\% & $-139,5552$ \\
5 & Shot Peening 0,0091 A, 200\% & $-170,5675$ \\
\hline
\end{tabular}

Dari hasil pengujian tegangan sisa pada tabel 3 diatas, diketahui bahwa tegangan sisa material awal (tanpa dilakukan proses shot peening) adalah 92,5021 MPa, tegangan sisa ini berupa tegangan sisa tarik (residual stress tension), tegangan sisa ini dapat timbul karena proses permesinan dan perlakuan panas yang dialami material Al 7075 T7351. Tegangan sisa tarik yang ada pada material awal tersebut dalam aplikasinya akan mempercepat terjadinya kegagalan terhadap suatu komponen jika diberi pembebanan baik berupa beban berulang maupun statis.

Sedangkan tegangan sisa pada material yang dilakukan proses shot peening pada permukaannya terjadi perubahan, yaitu tegangan sisa tekan (residual stress compression), seperti ditunjukkan pada tabel 3, yang dapat menghalangi awal terjadinya kegagalan pada daerah tegangan sisa tekan tersebut sehingga umur dari material dapat diperpanjang.

Berdasarkan hasil pengujian pada tabel 3, juga dapat diketahui bahwa proses penembakan dengan pelapisan permukaan (coverage) 200\% pada intensitas 0,0062 A, belum melampaui harga tegangan sisa tekan yang dihasilkan pada penembakan 0,0091 A. Kenaikan nilai tegangan sisa pada intensitas 0,0062 A dengan coverage 200\% lebih kecil dibandingkan dengan kenaikan yang dialami pada coverage $200 \%$ dengan intensitas $0,0091 \mathrm{~A}$, hal ini dapat 
disebabkan karena tekanan partikel shot yang lebih besar dan jarak dari permukaan material yang ditembak lebih dekat sehingga kenaikan tegangan sisa yang dialami pada intensitas 0,0091 A menjadi lebih besar.

Timbulnya tegangan sisa tekan pada permukaan material dapat terjadi karena efek penekanan yang besar, yang mengakibatkan dipermukaan material terjadi deformasi plastis sedangkan dibawahnya tetap dalam keadaan elastis (normal), oleh karena itu pada permukaan timbul tegangan sisa tekan sedangkan dibawah lapisan tersebut terdapat daerah tegangan sisa tarik yang mengimbanginya. Kedalaman lapisan tegangan sisa tekan pada permukaan material, berdasarkan gambar 3 dan 4 adalah antara $150-250 \mu \mathrm{m}$ untuk intensitas 0,0062 A, dan antara $250-350 \mu \mathrm{m}$ pada intensitas 0,0091 A.

Secara mekanika timbulnya tegangan sisa tekan pada permukaan dan tegangan sisa tarik pada bagian dalamnya dapat dijelaskan menurut hukum aksi reaksi, yaitu akibat aksi gaya tekan yang diberikan partikel shot, menyebabkan pada permukaan timbul tegangan sisa tekan, sementara pada daerah dibawahnya memberikan reaksi yang berlawanan sehingga terjadi tegangan yang melawan arah tembakan partikel shot.

\section{KESIMPULAN}

Proses shot peening menyebabkan terjadinya perubahan jenis tegangan sisa (residual stress) pada permukaan dari keadaan tarik sebesar 92,5021 MPa menjadi tekan antara $-111,8726$ MPa sampai -170,5675 MPa, serta meningkatnya kekerasan pada permukaan Aluminium 7075 T7351 dengan kedalaman pengaruh antara $150-350 \mu \mathrm{m}$.

Makin besar intensitas dan coverage yang diberikan, maka besarnya tegangan sisa dan kekerasan yang dihasilkan semakin besar. Peningkatan intensitas ternyata lebih mempunyai pengaruh besar dibandingkan peningkatan coverage menjadi $200 \%$ terhadap tegangan sisa dan kekerasan pada permukaan yang dihasilkan.

\section{DAFTAR PUSTAKA}

Campbell, F.C. (2008). Element of Metallurgy and Engineering Alloys. Ohio : ASM International.

Gariépy, A., Miao, H.Y., \& Lévesque, M. (2017). Simulation of the Shot Peening Process with Variable Shot Diameters and Impacting Velocities. Advances in Engineering Software, 114, 121-133.

Klotz, T., et al. (2018). Analytical Fatigue Life Prediction of Shot Peened Inconel 718. International Journal of Fatigue, 113, 204-221.

Klotz, T., D. Delbergue., P. Bocher., M. Levesque., \& M. Brochu. (2018). Surface Characteristics and Fatigue Behavior of Shot Peened Inconel 718. International Journal of Fatigue, 110, 10-21.

Liu, A., et al. (2001). Low Carbon Steel with Nanostructured Surfaces Layer Induced by High Energy Shot Peening. Scripta Mater, 44, 1791-1795. 
Mahmoudi, A.H., et al. (2016). A Comprehensive Experimental and Numerical Study on Redistribution of Residual Stresses by Shot Peening. Material and Design, 90, 478-487.

Nugroho, Aris W., \& Sunardi. (2017). Rekayasa Permukaan Shot Peening untuk Meningkatkan Sifat Mekanis dan Wettability pada Material Biomedik Plat Penyambung Tulang SS 316L. Lembaga Penelitian Universitas Muhammadiyah Yogyakarta.

Okido, Shinobu., et al. (2002). Preventive Effect of Shot Peening on Stress Corrosion Cracking. Material Science Research International, Vol.8, No.4, 193-198.

Torres, M.A.S., \& H.J.C.Voorwald. An Evaluation of Shot Peening, Residual Stress and Stress Relaxation on the Fatigue Life of AISI 4340 Steel. International Journal of Fatigue, 24, 877-886.

Zhao, Xiaohui., Hongyang Zhou., \&Liu Yu. (2018). Effect of Shot Peening on the Fatigue Properties of Nickel-Based Superalloy GH4169 at High Temperature.Result in Physics, 11, 452-460. 